\title{
Factors that affect the formation of networks for collaborative learning: an empirical study conducted at a Chilean university
}

\author{
Factores que afectan la formación de redes para el aprendizaje colaborativo: \\ un estudio empírico conducido en una universidad chilena \\ Patricio Ramírez-Correa $^{1} \quad$ Carolina Fuentes-Vega ${ }^{1}$ \\ Recibido 15 de noviembre de 2013, aceptado 30 de septiembre de 2014 \\ Received: November 15, 2013 Accepted: September 30, 2014
}

\begin{abstract}
This article shows the results of applying social network analysis techniques to explore the antecedents in the formation of collaborative learning networks in Chile. Immersed in learning analytics, the paper indicates a set of individual variables of students that explain the relationship structure between them for the purpose of collaborating in the study. In particular, the study used a Multiple Regression Quadratic Assignment Procedure to analyze a network of students belonging to a Chilean university. The results support the existence of three antecedents in the formation of a network to collaborate in the learning: homophily, closeness in the academic performance and looseness in the happiness level.
\end{abstract}

Keywords: Learning analytics, social network analysis, happiness, higher education, Chile.

\section{RESUMEN}

Este artículo muestra los resultados de la aplicación de técnicas de análisis de redes sociales para explorar los antecedentes en la formación de redes de aprendizaje colaborativo en Chile. Inmerso en el análisis de aprendizaje, este trabajo señala un conjunto de variables individuales que explican la estructura de las relaciones entre los estudiantes con el propósito de colaborar en el estudio. En particular, el estudio utilizó una regresión múltiple basada en el procedimiento de asignación cuadrática para analizar una red de estudiantes pertenecientes a una universidad chilena. Los resultados apoyan la existencia de tres antecedentes en la formación de una red para colaborar en el aprendizaje: homofilia, cercanía en el rendimiento académico y cercanía en el nivel de felicidad.

Palabras clave: Análisis de aprendizaje, análisis de redes sociales, felicidad, educación superior, Chile.

\section{INTRODUCTION}

As a result of the strong growth in the higher education coverage, currently in Chile $34 \%$ of people aged between 18 and 24 are studying in tertiary education [1], this has quintupled university enrolment in the last 25 years [2]. This growth has allowed entry into the system for socioeconomic groups that until recently had almost no participation in tertiary education [3]. Most of the students of these new groups have shortages in their previous academic formation. This new reality has created new challenges for universities in subjects such as academic performance and retention of students [3-4].

The higher education literature adopted the term analytics to refer to "the use of data, statistical analysis, and explanatory and predictive models to gain insights and act on complex issues"[5]. Anchored in the conceptualization of an organization

1 Escuela de Ciencias Empresariales. Universidad Católica del Norte. Larrondo 1281. Coquimbo, Chile.

E-mail: patricio.ramirez@ucn.cl; cfuentes@ucn.cl 
in a globalized and rapidly changing environment $[6,7]$, this term has had a remarkable growth in its application in the global context [8]. There are two main types of analytical applications in higher education, the first type aimed at the benefit of students and faculties, called learning analytics, and the second type aimed at the benefit of managers and government, called academic analytics [8].

Within learning analytics, it is a key issue to find patterns of success in the teaching process, and particularly, in the identification of at-risk students, which is the focus of recent studies [9-11]. The identification of at-risk students is a prediction task which seeks to identify students at risk of academic underachievement in order to intervene and increase their chance of success [8].

Identifying students at academic risk is a complex problem of various dimensions. To support the analysis of this problem in the context of Chilean higher education, this research is placed from the perspective of collaborative learning model.

Situated within the social constructivism paradigm, the collaborative learning model assumes that learning emerges from the interaction of an individual with another $[12,13]$. Therefore, the collaborative network is critical to the academic success of a student. The student is on academic risk if he or she is not integrated into a collaborative network. How is a collaboration network created amongst students? What individual characteristics are important to participate in it? In this paper we explore in the search for answers to these questions. In short, the objective of this study is to identify, in a sample of Chilean university students, individual attributes that predict the conformation of a collaborative network for study.

This article is structured as follows. First, the literature review presents a brief review of the election of members of a team and our hypothesis. Next we present the methodology followed by the results. Finally, we present the conclusions.

\section{LITERATURE REVIEW}

In the literature about teams, a social network is defined as a set of nodes and a set of ties representing some relationship between the nodes within a small group [14]. For this study, and based on Klein, Lim, Saltz, and Mayer [15], collaborative learning network is comprised of relations through which students share resources such as information, tips, and guidance to learn.

Studies about social networks have focused on the consequences of their configuration rather than its configuration antecedents [15]. Nevertheless, choosing team members has been studied in previous literature. In general, evidence indicates that people combine instrumentality and feelings in their working relationships [16].

Homophily, the tendency for people to be attracted to similar others, has been proposed as an antecedent for choosing team members [15, 17]. Individuals tend to associate with people with similar characteristics such as the same gender, age or educational level. Therefore, students generate collaborative networks for learning based on the choice of students like them. Considering the above, we propose that the similarity of gender, the city where she/he lives and his/her previous high school are antecedents when establishing ties to study in college. Based on previous studies we proposed the following hypothesis:

\section{H1: A student creates relationships for collaborative learning based on homophily.}

Additionally, reputation for competence has been proposed as an antecedent for choosing team members [15, 17-18]. When individuals select work partners, these people try to choose those individuals who have a reputation for being competent and hardworking. Therefore, when a student chooses another student to study, the student will tend to find a student with high academic achievement. Since the other students behave in the same way, the result is that students are grouped according to their academic performance. Considering the above, we propose that the similarity of academic achievement is an antecedent when establishing ties to study in college. Based on previous studies we proposed the following hypothesis:

H2: A student creates relationships for collaborative learning based on his/her reputation for competence.

Happiness can be defined as the shorthand reference to the frequent experience of positive emotions [19]. 
Literature indicates that happy people are successful in multiple domains of life, such as marriage, friendship, work, performance, salary and health, which implies a causal relationship between success and happiness [19, 20]. Fowler and Christakis [21] have noted the influence of our colleagues happiness in our own happiness. When classmates of a student increase their level of happiness this student's also increases, and when they decrease their level of happiness, the student's also decreases. In a recent study Ramirez and Fuentes [22] demonstrated the moderating effect of happiness on the performance of university students. Considering the above, we propose that the similarity of the level of happiness is an antecedent when establishing ties to study in college. Based on previous studies we proposed the following hypothesis:

\section{H3: A student creates relationships for collaborative learning based on his/her level of happiness.}

\section{METHODOLOGY}

\section{Sample}

The empirical study was based on a sample of non-random convenience which was conducted in November 2012. The survey was answered by students of the undergraduate business program at the Universidad Católica del Norte, located in the city of Coquimbo (Chile). This program has a total of 365 regular students. The final sample size was 176 students, $60.8 \%$ (107) females and 39.2\% (69) males, a proportion that was in correspondence to the total students in the program. Moreover, respondents are distributed in program levels similar to total students enrolled in it.

\section{Method}

First, in order to capture the collaborative network learning, each student was asked about their relationships with other students for studying, specifically, each student was asked to identify all their fellow students and then indicate the frequency in which they study with each of them (on a scale of $1=$ once to $5=$ very often).

Next, we build a database with the attributes of the nodes; each student was a network node. We took gender, city where student lives, and previous high school as individual variables associated with homophily. In addition, we considered academic performance scores and weighted academic performance scores as individual variables associated with the reputation for competence. Academic performance scores and student characteristics were taken from the official databases of the university. Measuring subjective happiness was based on the scale of Lyubomirsky and Lepper [23] (see Appendix A).

For pre-processing the level of happiness and academic performance scores the absolute difference between the scores of each pair of students was calculated. Therefore, if two students have the same score then this difference is zero, and this value increases proportionally to the difference between two students.

Finally, we conducted a multiple regression quadratic assignment procedures (MRQAP) analysis to test hypothesis. MRQAP was conducted in UCINET Version 6 using the Double- Dekker Semi Partializing. Technique [24].

Since standard statistical approaches assume that the observations were mutually independent, and in a network model this does not happen, it was necessary to use other tools [24-25]. MRQAP is a non parametric technique based on simulation; in particular, it uses permutations of the data set [26]. Thereby, MRQAP allows the analysis on dyadic data and overcomes the problem of nonindependent observations [26-27]. Normally, this technique is applied in the analysis of a network when the intention is to control any specific effect on it. In the literature, MRQAP has been proposed as a useful predictive tool in social sciences [24, 27].

\section{RESULTS}

Figure 1 and Figure 2 show the collaborative learning network. In these figures, nodes are grayscale according to the student's city, and their shapes represent the student's gender (circles to females, squares to males). In Figure 1, node sizes are proportional to the student's academic performance score. In Figure 2, node's size is proportional to the student's happiness score.

Table 1 shows the results of MRQAP. The findings indicated that the same gender $(0.042 ; \mathrm{p}<0.001)$, the same city $(0.023 ; \mathrm{p}<0.001)$ and the same previous 


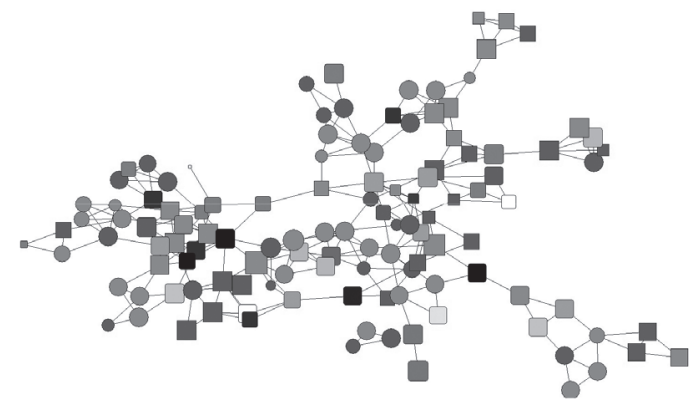

Figure 1. Collaborative learning network, node sizes are proportional to the student's academic performance score.

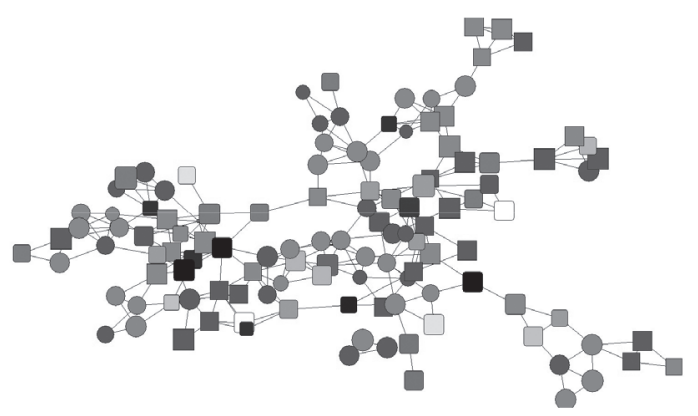

Figure 2. Collaborative learning network, node sizes are proportional to the student's happiness score.

high school $(0.056 ; \mathrm{p}<0.001)$ were determinants of a group member's choice in a network collaborative learning. These results supported H1. Additionally, the findings indicated that similar academic performance scores $(-0.030 ; \mathrm{p}<0.001)$ and similar weighted academic performance scores $(-0.015$; $\mathrm{p}<0.05$ ) were determinants of group member choice in a network collaborative learning. These results supported H2. Finally, the analysis indicated that the similarity in the happiness score $(-0.016$; $p$ $<0.05$ ) determined the choice of group member in a network of collaborative learning. This result supported $\mathrm{H} 3$.

Although studies exist in the literature in other geographical areas with similar results that support the first and second hypothesis [15, 17-18, 28-29], our work presents the first contribution that explores this phenomenon in Chilean universities.
Table 1. Multiple regression QAP predicting i's choice of $\mathrm{j}$ as partner for collaborative learning.

\begin{tabular}{|c|c|c|}
\hline & 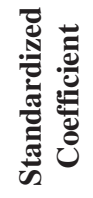 & $\ddot{n}$ \\
\hline \multicolumn{3}{|l|}{ H1: Homophily } \\
\hline Same gender & .042 & $* * *$ \\
\hline Same city & .023 & $* * *$ \\
\hline Same high school & .056 & $* * *$ \\
\hline \multicolumn{3}{|l|}{ H2: Reputation for competence } \\
\hline Academic performance scores & -.030 & $* * *$ \\
\hline $\begin{array}{l}\text { Academic performance scores } \\
\text { weighted }\end{array}$ & -.015 & $*$ \\
\hline \multicolumn{3}{|l|}{ H3: Happiness } \\
\hline Happiness score & -.016 & $*$ \\
\hline
\end{tabular}

Sig. $* \mathrm{p}<.05 ; * * \mathrm{p}<.01 ; * * * \mathrm{p}<.00$.

\section{CONCLUSIONS}

The main objective of this work is to identify individual attributes that predict the formation of a collaborative network for the study in a sample of Chilean university students. To achieve this main objective three hypotheses were developed. The empirical analysis results support each of these.

The first hypothesis explains that the creation of a collaborative learning network is based on the similarities between its members. In particular, gender, city of residence and establishment of secondary education are individual attributes that predict whether a relationship will be established with other students. In this sense, some reflections may be mentioned. On one hand, gender is configured as an important key to differentiation, and we know that this type of polarization is a bad strategy to confront an increasingly complex issue, and otherwise having different views in a team (both men and women) is a good strategy. On the other hand, the fact that the institution of secondary education is an attribute to select study partners in college could be rooted in the huge segregation that exists in Chile between public school students and private school students.

The second hypothesis explains the formation of the network collaborative learning is based on similar 
academic performance. In particular, the academic performance and weighted academic performance of the courses are individual attributes that predict whether a relationship will be established with other students or not.

The third hypothesis explains that the creation of a collaborative learning network is based on the similarities in the levels of happiness. That is, an index of subjective happiness reported by the individual predicts whether a relationship will be established with other students. This result is original and suggests various alternatives of intervention in the Chilean university classrooms. For example, the level of happiness predicts how a network of collaborative learning will be, and that high levels of happiness spread faster than lower levels of happiness [21]. Is it possible to increase overall performance of student teams if we integrate individuals with lower levels of happiness to successful student teams? Perhaps this is an alternative to help academically at-risk students.

In general, the overall purpose of this study has been achieved, and therefore, it is possible indicate that there are three determinants of participation in a collaborative network: homophily, closeness in academic performance, and closeness in the happiness level. Given this fact, the exploring of interventions to promote the integration of students at academic risk to these collaborative networks is an important future challenge.

Following, we wish to deliver a set of general conclusions based on the findings of the study.

First, the difference in academic performance between a student and the other students conditions whether this student collaborates with learning or not, ie, when the difference is smaller, it's more possible that a student will collaborate with a peer. Therefore, students with good academic performance prefer to collaborate with each other, disregarding students with lower academic performance. This finding supports the idea of collaboration being critical to successful learning.

Second, similar levels of happiness positively affect the creation of partnerships between two students for learning. Given, on the one hand, that study is the main activity of a higher student, and that this behaviour is due to both the intention of this behaviour and of the habit associated to this behaviour, and secondly, that students with higher happiness levels encourage the creation of a network of students with equal happiness levels, and that a greater number of relationships with happy individuals increase an individual's happiness level, it is possible that in a group of academically successful students, a double spiral is generated which in turn increases study habits and an individual's happiness. Unfortunately, this doesn't apply to unsuccessful students, increasing their academic risk.

And third, although the results of this study are limited to the activity of tertiary students, we know that in multiple contexts their behaviour relates closely to similar phenomena in professional environments. Therefore, it is expected that in professional contexts where collaboration is necessary for learning such as consulting projects or business innovation activities - the findings of this study may be useful.

Finally, it is advisable to set out some limitations. Firstly, the study was cross-sectional; we recommend future works to develop a longitudinal study. Also, students who participated in the study belong to a business undergraduate program, and we cannot extrapolate all results to other undergraduate programs where students have different personality traits.

\section{REFERENCES}

[1] P. Ramírez-Correa, J. C. Peña-Vinces and J. Alfaro-Pérez. "Evaluating the efficiency of the higher education system in emerging economies: Empirical evidences from Chilean universities". African Journal of Business Management. Vol. 6 No $^{\circ}$, pp. 1441-1448. 2012.

[2] L.E. González and O. Espinoza. "Estado actual del sistema de aseguramiento de la calidad y el régimen de acreditación en la educación superior en Chile". Revista de la Educación Superior. Vol. 41 No 162, pp. 87109. 2012.

[3] G. Fonseca. "Tendencias actuales sobre equidad en educación superior en Chile y sus antecedentes internacionales". Revista de Estudios y Experiencias en Educación. Vol. 10 No $^{\circ}$ 19, pp. 91-103. 2013. 
[4] M.P. Mogollón and M. Crawford. Reviews of National Policies for Education: Tertiary Education in Chile. OECD Publishing. Paris, Francia. 2009.

[5] J. Bichsel. "Analytics in Higher Education: Benefits, Barriers, Progress and Recommendations". EDUCAUSE Center for Applied Research. Louisville. 2012.

[6] T.H. Davenport. "Competing on analytics". Harvard Business Review. Vol. $84 \mathrm{~N}^{\circ} 1$, pp. 98. 2006.

[7] T.H. Davenport and J.G. Harris. Competing on analytics: the new science of winning. Harvard Business School Press, Boston. 2007.

[8] M. van Harmelen and D. Workman. "Analytics for Learning and Teaching". CETIS Analytics Series. Vol. 1 N$^{\circ}$ 3, pp. 1-40. 2012.

[9] A. Wolff, Z. Zdrahal, A. Nikolov and M. Pantucek. "Improving retention: predicting at-risk students by analysing clicking behaviour in a virtual learning environment". Proceedings of the Third International Conference on Learning Analytics and Knowledge, pp. 145-149. 2013.

[10] V.C. Smith, A. Lange and D.R. Huston. "Predictive Modeling to Forecast Student Outcomes and Drive Effective Interventions in Online Community College Courses". Journal of Asynchronous Learning Networks. Vol. $16 \mathrm{~N}^{\circ}$ 3, pp. 51-61. 2012.

[11] A. Essa and H. Ayad. "Student success system: risk analytics and data visualization using ensembles of predictive models". Proceedings of the 2nd International Conference on Learning Analytics and Knowledge, pp. 158161. 2012.

[12] B. Lin and C.-t. Hsieh. "Web-based teaching and learner control: A research review". Computers \& Education. Vol. $37 \mathrm{~N}^{\circ} 3$, pp. 377-386. 2001.

[13] M. Cole. "Using Wiki technology to support student engagement: Lessons from the trenches". Computers \& Education. Vol. 52 No 1, pp. 141-146. 2009.

[14] K. Henttonen. "Exploring social networks on the team level-A review of the empirical literature". Journal of Engineering and Technology Management. Vol. $27 \mathrm{~N}^{\circ} 4$, pp. 74-109. 2010.

[15] K.J. Klein, B.-C. Lim, J.L. Saltz and D.M. Mayer. "How do they get there? An examination of the antecedents of centrality in team networks". Academy of Management Journal Vol. 47 No 6, pp. 952-963. 2004.

[16] T. Casciaro and M.S. Lobo. "When competence is irrelevant: The role of interpersonal affect in task-related ties". Administrative Science Quarterly. Vol. 53 No 4, pp. 655-684. 2008.

[17] P.J. Hinds, K.M. Carley, D. Krackhardt, and D. Wholey. "Choosing work group members: Balancing similarity, competence, and familiarity". Organizational behavior and human decision processes. Vol. $81 \mathrm{~N}^{\circ} 2$, pp. 226-251. 2000.

[18] J.S. Bunderson. "Team member functional background and involvement in management teams: Direct effects and the moderating role of power centralization". Academy of Management Journal. Vol. $46 \mathrm{~N}^{\circ}$ 4, pp. 458474. 2003.

[19] S. Lyubomirsky, L. King and E. Diener. "The benefits of frequent positive affect: Does happiness lead to success?'. Psychological Bulletin. Vol. 131 No 6, pp. 803-855. 2005.

[20] F. Scorsolini-Comin and M.A. dos Santos. "Positive Affection Measurement: Subjective Well-Being in Married People". PsicologiaReflexao E Critica. Vol. 25 N $^{\circ}$ 1, pp. 11-20. 2012.

[21] J.H. Fowler and N.A. Christakis. "Dynamic spread of happiness in a large social network: longitudinal analysis over 20 years in the Framingham Heart Study”. British Medical Journal. Vol. 337. 2008.

[22] P.E. Ramírez and C.A. Fuentes. "Felicidad y Rendimiento Académico: Efecto Moderador de la Felicidad sobre Indicadores de Selección y Rendimiento Académico de Alumnos de Ingeniería Comercial". Formación universitaria. Vol. 6, $\mathrm{N}^{\mathrm{o}}$ 3, pp. 21-30. 2013.

[23] S. Lyubomirsky and H.S. Lepper. "A measure of subjective happiness: Preliminary reliability and construct validation". Social Indicators Research. Vol. 46 N 2, pp. 137155. 1999.

[24] D. Dekker, D. Krackhardt and T.A. Snijders. "Sensitivity of MRQAP tests to collinearity and autocorrelation conditions". Psychometrika. Vol. 72, No 4, pp. 563-581. 2007.

[25] G. Robins, J.M. Lewis and P. Wang. "Statistical network analysis for analyzing 
policy networks". Policy Studies Journal. Vol. $40 \mathrm{~N}^{\mathrm{o}}$ 3, pp. 375-401. 2012.

[26] W. Simpson. "QAP: The quadratic assignment procedure". North American Stata Users' Group Meeting. 2001.

[27] D. Krackhardt. "Predicting with networks: Nonparametric multiple regression analysis of dyadic data". Social networks. Vol. 10 $\mathrm{N}^{\circ}$ 4, pp. 359-381. 1988.

[28] H. Yang and J.-H. Tang. "Effects of social network on students' performance: a webbased forum study in Taiwan". Journal of Asynchronous Learning Networks. Vol. 7 No 3, pp. 93-107. 2003.

[29] G. Fattore and D. Salvatore. "Network organizations of general practitioners: antecedents of formation and consequences of participation". BMC health services research. Vol. $10 \mathrm{~N}^{\circ} 118$, pp. 1-12. 2010.

\section{APPENDIX A: ITEMS OF HAPPINESS SCALE}

All items were measured on a 7-point Likert scale.

Item 1: In general, I consider myself (1: not a very happy person; 7: a very happy person)

Item 2: Compared to most of my college mates, I consider myself: (1: less happy; 7: more happy) Item 3: Some people are generally very happy. They enjoy life regardless of what is going on, getting the most out of everything. To what extent does this characterization describe you? (1: not at all; 7: a great deal)

Item 4: Some people are generally not very happy. Although they are not depressed, they never seem as happy as they might be. To what extend does this characterization describe you? (1: not at all; 7: a great deal). 